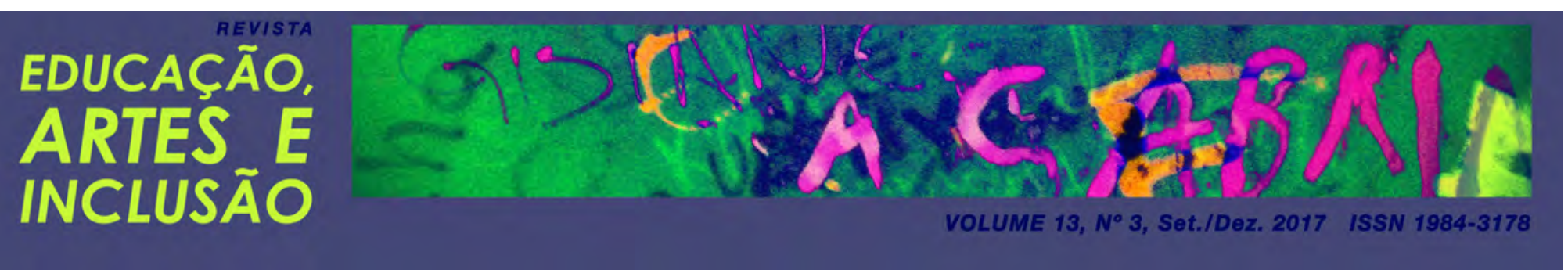

\title{
A IMPLANTAÇÃO DA LIBRAS NAS LICENCIATURAS: DESMISTIFICANDO CONCEITOS
}

\section{IMPLEMENTATION OF LIBRAS IN UNDERGRADUATE EDUCATION: DEMYSTIFYING CONCEPTS}

\section{DOI: http://dx.doi.org/10.5965/1984317813032017073}

Rejane de Aquino Souza - Universidade Federal de Mato Grosso do Sul

\begin{abstract}
RESUMO
Este artigo objetiva apresentar uma investigação sobre a Língua Brasileira de Sinais (Libras) como disciplina curricular obrigatória nos cursos de licenciatura, no sentido de apontar sobre a sua importância para a desmistificação em torno dos conceitos de surdo e de Libras, nos professores em formação. Trata-se de uma pesquisa de campo com abordagem qualitativa. Metodologicamente, foram aplicados dois questionamentos a treze acadêmicos de licenciatura, necessariamente matriculados na disciplina de Libras, e que aceitaram participar da investigação, sendo o primeiro questionamento no início do semestre letivo, e o segundo no seu término. Nos dois momentos, os participantes escreveram, de próprio punho, sobre o entendimento de dois termos: surdo e Libras. O intuito era a verificação se haveria mudança de conceitos sobre o surdo e a Libras, durante a disciplina. Os resultados permitem considerar que a inserção de tal disciplina na licenciatura, de fato, tem relevância, pois, verificou-se que a mesma pode contribuir com a alteração dos conceitos em questão, aprimorando, assim, o conhecimento dos professores em formação sobre o surdo e a Libras.
\end{abstract}

Palavras-chave: Língua Brasileira de Sinais. Licenciatura. Docência. Inclusão.

\begin{abstract}
This article aims to present an investigation about the Brazilian Language of Signals (Libras) as a required curricular discipline in undergraduate courses, in order to point out its importance for the demystification around the concepts of deaf and Libras in the teachers in formation. This is a field research with a qualitative approach. Methodologically, two questions were applied to thirteen undergraduate students, necessarily enrolled in the discipline of Libras, and who accepted to participate in the investigation, being the first questioning at the beginning of the semester, and the second in its finished. In the two moments, the participants wrote, in their own hand, on the understanding of the two terms: deaf and Libras. The intention was to verify if there would be a change of concepts about the deaf and the Libras during the discipline. The results allow to consider that the insertion of such discipline in the undergraduate, in fact, has relevance, therefore, it was verified that it can contribute with the alteration of the concepts in question, thus improving the knowledge of the teachers in formation on the deaf and Libras.
\end{abstract}

Keywords: Brazilian Language of Signals. Teacher's Education. Teaching. Inclusion. 


\section{INTRODUÇÃO}

Desde o ano de 2005 foi estabelecida a implantação da Língua Brasileira de Sinais (Libras) como disciplina curricular nos cursos de licenciatura por todo o Brasil, conforme determina o artigo terceiro do Decreto $\mathrm{n}^{\circ} 5.626 / 2005$ :

Art. $3^{\circ}$ A Libras deve ser inserida como disciplina curricular obrigatória nos cursos de formação de professores para o exercício do magistério, em nível médio e superior, e nos cursos de Fonoaudiologia, de instituições de ensino, públicas e privadas, do sistema federal de ensino e dos sistemas de ensino dos Estados, do Distrito Federal e dos Municípios.

$\S 1^{\circ}$ Todos os cursos de licenciatura, nas diferentes áreas do conhecimento, o curso normal de nível médio, o curso normal superior, o curso de Pedagogia e o curso de Educação Especial são considerados cursos de formação de professores e profissionais da educação para o exercício do magistério.

$\S 2^{\circ}$ A Libras constituir-se-á em disciplina curricular optativa nos demais cursos de educação superior e na educação profissional, a partir de um ano da publicação deste Decreto. (BRASIL, 2005, p. 1).

Pelo que ficou estabelecido no documento, as Instituições de Ensino Superior (IES) do país iniciaram uma mobilização para estabelecer a implantação da mencionada disciplina nas suas graduações para o magistério. Dessa maneira, percebe-se, na atualidade, uma movimentação em termos de abertura de editais de concursos públicos para a efetivação de professores para o preenchimento da mencionada cadeira, ou em termos de contratações de docentes nas instituições privadas com o mesmo fim.

De acordo com Gesser (2009), tal documento decorreu do grande ativismo da comunidade surda brasileira que vem lutando pelo reconhecimento da Libras como Língua verdadeira, e pelo respeito e ascensão da minoria surda. Para a autora, a necessidade do estabelecimento desse Decreto e de outros documentos referentes ao mesmo público, qual seja, o surdo, decorre de uma série de razões históricas que se relacionaram com a segregação, o desrespeito, a dominação, enfim, com todas as atitudes ouvintistas (hegemonia do ouvinte em detrimento do surdo, de acordo com a autora) que estabeleceram intensas barreiras nas várias instâncias sociais para o surdo, especialmente na área educacional, e, ainda, desvalorizaram a língua de sinais, que no Brasil, trata-se da Libras. 
Gesser (2009) afirma que na atualidade permeiam em torno do surdo e da Libras diversos mitos e preconceitos que advêm, justamente, desse processo histórico-social ligado ao ouvintismo, conforme explicado no parágrafo anterior. Uma das barreiras elencadas pela autora diz respeito ao âmbito educacional, por meio da presença de diversos mitos e preconceitos que causam prejuízos no processo acadêmico dos alunos surdos em situação de inclusão.

Assim, elegeu-se para a discussão desta produção, a verificação da necessidade e da importância da cadeira de Libras na formação para o magistério, a fim de se investigar se a presença dessa disciplina acadêmica possibilita um preparo adequado da prática pedagógica, no caso aqui, na presença do aluno surdo em situação de inclusão. O intuito foi verificar se a referida disciplina contribui para a dissolução dos mitos e dos preconceitos em torno do surdo e da Libras, que são instalados historicamente na racionalidade social. Especificamente, objetivou-se analisar se os acadêmicos de licenciatura (participantes da pesquisa) aprimoraram suas concepções em relação ao surdo e à Libras por meio das discussões e dos estudos possibilitados pela inserção da disciplina de Libras.

Esta produção justifica-se, portanto, pela necessidade de verificação da hipótese a respeito da extrema relevância da implantação obrigatória da disciplina de Libras na grade curricular das diversas licenciaturas, em função da desmistificação de conceitos equivocados (dissolução de mitos e de preconceitos instalados social e historicamente) na direção dos surdos e da Libras. Tal relevância se conjectura no fato de que as licenciaturas preparam profissionais para atuarem na educação, ou seja, preparam futuros educadores. Assim sendo, estes precisam estar aparelhados de conhecimentos fundamentados para lidar com a heterogeneidade, e no caso em questão, com a presença do aluno surdo em situação de inclusão. Espera-se que, com esse preparo ainda na formação universitária, os pretensos educadores atuem em vista do bem do aluno surdo no que se refere ao seu processo educativo. Isto por meio de uma prática pedagógica refletida e que evite a recorrente reprodução de mitos e de preconceitos relacionados ao surdo e à Libras no meio escolar.

Objetivou-se estabelecer a proposição sobre a extrema importância da cadeira de Libras nas licenciaturas, de um lado, com o intuito de valorizá-la, e de outro, para demonstrar que por ela se pode promover a desmistificação em relação aos temas Libras e surdo no meio educacional, fomentando, assim, uma práxis pedagógica de qualidade. Dessa maneira, 
buscou-se analisar o entendimento dos alunos de licenciatura em Geografia, frequentes na disciplina de Libras, sobre os elementos surdo e Libras, no início e no final do semestre letivo. O intento residiu na verificação se houve ou não mudança nas respostas dos acadêmicos, no início e no término da disciplina, de modo que, no início poderia haver alguma resposta pautada no senso comum, e no seu término poderia haver respostas baseadas nos preceitos dos Estudos Surdos, ou seja, no conhecimento abalizado e oportunizado a partir da disciplina de Libras.

Trata-se de uma pesquisa de campo com abordagem qualitativa. As bases teóricometodológicas foram estruturadas a partir do levantamento bibliográfico concernente aos elementos relacionados com o objeto da pesquisa: surdo e Libras; seguida de dois momentos práticos específicos, o primeiro no início do semestre letivo de 2014/2, e o segundo no término deste. Esses dois momentos ocorreram numa universidade pública federal com acadêmicos de licenciatura do curso de Geografia, em que, necessariamente, estavam matriculados na disciplina de Libras, e que aceitaram participar da investigação. A escolha do curso foi aleatória, já dos acadêmicos foi o fato de estarem matriculados na disciplina de Libras e de aceitarem participar da investigação, assim, somaram-se treze participantes.

O questionamento sobre a concepção desses alunos acerca do surdo e da Libras foi realizado por meio da solicitação de dois registros por escrito em dois momentos distintos, um no início e o outro no término do semestre letivo em questão, de modo que os acadêmicos deveriam escrever, de próprio punho, em folhas entregues pela pesquisadora, sobre o entendimento a respeito desses dois elementos: surdo e Libras. Posteriormente, foi realizada a análise dos resultados, a discussão com a teoria e, por fim, o registro conclusivo de todo o estudo.

Este artigo traz, primeiramente, um levantamento bibliográfico conceitual acerca dos elementos pertinentes à discussão, no caso, as concepções de surdo, o conceito e as considerações sobre a Libras, e sobre a presença desta na academia como disciplina obrigatória para a formação de educadores. Posteriormente, traz os registros dos acadêmicos sobre o entendimento de surdo e de Libras no início e no fim do semestre letivo. E, por último, apresenta uma análise desses registros por meio da articulação com o levantamento bibliográfico intuindo verificar sobre a importância da implantação da Libras como disciplina curricular obrigatória nas licenciaturas. 


\section{CONCEITOS RELACIONADOS}

Antes de adentrar na temática específica, se faz necessária a abertura da presente seção com a conceituação de alguns elementos relacionados, tanto para melhor compreensão, quanto para o embasamento desta investigação. Tais elementos se referem às concepções de surdo, às considerações teóricas sobre a Libras, e, finalmente, à fundamentação acerca da Libras na academia, especificamente, nas graduações de licenciatura.

\subsection{O SURDO}

Falar de Libras, seja na academia ou em qualquer outro aspecto, demanda na necessidade de se explanar anteriormente em relação a seus utentes mais significativos, isto é, os surdos.

De acordo com Quadros e Karnopp (2004), há surdos usuários de Libras e há ouvintes que, também, fazem uso dessa Língua por terem contato direto com esses surdos. Dessa forma, Gesser (2009) explica que a comunidade surda brasileira é constituída por surdos e por ouvintes, sendo estes últimos, familiares e amigos dos surdos, e profissionais como tradutores/intérpretes, professores, entre outros.

Em relação aos utentes de Libras aqui identificados como mais significativos, isto é, os surdos, Gesser (2009) afirma que há duas vertentes específicas no que concerne a sua concepção: a perspectiva médica e a dos Estudos Surdos.

Conforme a autora, a perspectiva médica (também chamada de clínico-terapêutica, ambulatorial, ou ainda, organicista) preza pelo sentido da audição como condição necessária e vital para que uma pessoa possa estar em sociedade, ou seja, possa trabalhar, estudar, enfim, conviver equiparada e harmoniosamente com os demais. De acordo com Gesser (2009) e com as contribuições de Deus (2010), diante da perspectiva médica há um intenso fomento para o diagnóstico precoce da surdez com o intuito de se possibilitar a sua "correção" por meio do uso de aparelhos de amplificação sonora ou do implante de um eletrodo ligado diretamente ao nervo auditivo, conhecido como implante coclear, tudo isso, obviamente, que de acordo com a causa, o grau e o tipo de surdez. As autoras convergem em seus estudos sobre o fato de haver, também, na perspectiva médica uma preocupação acerca da reabilitação da fala oral, na qual 
consiste em um trabalho de acompanhamento com uma rede multidisciplinar, com foco principal na fonoterapia.

A intenção expressa de tal perspectiva relaciona-se, nitidamente, com a tentativa de "cura" da surdez, a fim de se alcançar a "normalidade" e a "padronização", ou seja, a surdez não é aceita como uma diferença, mas sim como uma patologia, uma deficiência que precisaria ser curada e/ou corrigida, conforme explicam Gesser (2009) e Deus (2010).

Já para a perspectiva dos Estudos Surdos, estes são compreendidos de forma completamente distinta da visão organicista. Seus autores apontam as maneiras equivocadas nas quais os surdos foram percebidos e tratados ao longo da história da humanidade. Em contrapartida, abordam sobre outra concepção acerca da pessoa surda que se baseia no reconhecimento das diferenças ligadas as suas peculiaridades: especialmente a língua de sinais.

Ao longo da história da humanidade, segundo Pinheiro (2010), os surdos foram tratados de forma desumana e com descaso, eles não eram aceitos e por isso não podiam fazer parte das sociedades.

$\mathrm{Na}$ era nômade e tribal da pré-história, nas civilizações antigas e na idade média, os surdos, ou qualquer sujeito diferente, eram tratados com extrema crueldade, eram aprisionados em porões ou asilos, eram rejeitados, abandonados à própria sorte, mantidos como escravos, indigentes, e o mais espantoso, eram assassinados. De acordo com a mesma autora, tais atitudes se deram devido às crenças dessas respectivas épocas, nas quais se baseavam no ideário de que havia algum castigo das divindades, ou que essas crianças poderiam contaminar outras pessoas, ou eram vistas como causa de vergonha para as suas famílias, ou ainda, como estorvos já que eram entendidas como irracionais, improdutivas e incapazes de conviver em sociedade.

No fim da idade média, segundo Veloso e Maia (2011), surgiu alguma alusão diferente dos aspectos mencionados acima, foi quando Bartollo d'Ancora, um advogado europeu do século XIV, expressou sua reflexão acerca da capacidade do surdo para aprender através da língua de sinais. 
Mais tarde, já na idade moderna, os mesmos autores citam outras personalidades importantes, trata-se de alguns religiosos, estudiosos, médicos e educadores que se interessaram, estudaram, pesquisaram e expressaram diferentes visões acerca do surdo. Os principais personagens neste sentido foram o médico italiano Girolamo Cardano, o monge espanhol beneditino Ponce de Léon, e o intelectual espanhol Pablo Bonet, todos estes no século XVI; já no século seguinte surgiram os educadores ingleses John Wallis e George Dalgarno, e o médico suíço Johann Amman; e no século XVIII surgiram o educador alemão Samuel Heinicke, o abade francês Charles de l'Epée, e o médico italiano Jean Itard; no século XIX foi a vez do educador americano Thomas Gallaudet, e dos educadores surdos franceses Ernest Huet e Laurent Clerc. Diante do que apregoava cada um dos personagens acima mencionados, Veloso e Maia (2011) esclarecem que os surdos foram entendidos e tratados nas suas sociedades de diferentes maneiras. Os autores explicam que, por vezes, foram entendidos como incompetentes e inferiores aos ouvintes, foram obrigados a falar e a ouvir como tentativa de igualá-los aos ouvintes, e foram submetidos a diversas intervenções médicas, tratamentos e terapias. Todos esses equívocos geraram preconceitos históricos e concepções pejorativas na sociedade, tais como "mudinho", "surdo-mudo", "deficiente", entre outras nomeações que não se adéquam à realidade do povo surdo. Entretanto, Veloso e Maia (2011) apontam que alguns dos nomes supracitados, especialmente l’Epée, foram visionários acerca da peculiaridade da língua de sinais como meio importante de comunicação e de apreensão de conhecimentos pelos surdos.

Nos séculos XX e XXI surgiram inúmeros estudiosos, pesquisadores, cientistas, educadores e ativistas por todo o mundo, tanto surdos quanto ouvintes ligados aos Estudos Surdos, tais como, os americanos Carol Padden e Willian Stokoe, as brasileiras Gladis Perlin e Ronice Quadros, além de outros nomes contemporâneos.

Para Perlin (2003), com o avanço dos estudos e das recentes pesquisas, e, ainda, por conta da constante e intensa luta do povo surdo e das comunidades surdas, atualmente a concepção de surdez está bem distinta dos tempos anteriores, primando agora por respeito, dignidade e cidadania. Pelas recentes mudanças nota-se que a língua de sinais foi oficializada e que o surdo tem sido foco de políticas públicas específicas que objetivam promover a sua inclusão na sociedade mediante reconhecimento de suas peculiaridades. Contudo, ainda há 
vários obstáculos a serem enfrentados, como os preconceitos e os mitos sobre o surdo e a Libras.

Perlin e Miranda (2003 apud SILVEIRA; REZENDE, 2008, p. 60) afirmam: "Ser surdo é uma questão de vida. Não se trata de uma deficiência, mas de uma experiência visual." Observa-se, segundo os autores, que o ser surdo não se define exatamente pela surdez em si, mas sim, pelo aspecto vivencial da visão e da língua de sinais que é visual e espacial, a qual será feita uma breve explanação na subseção seguinte.

\subsection{A LÍNGUA BRASILEIRA DE SINAIS}

Como dito nos itens anteriores, todos os eminentes esclarecimentos com base em estudos e pesquisas e, principalmente, por conta do forte e incansável ativismo surdo, a Língua Brasileira de Sinais, conhecida como Libras, foi oficializada pela Lei $n^{0} 10.436 / 2002$, e regulamentada pelo Decreto $\mathrm{n}^{0} 5.626 / 2005$, sendo, então, reconhecida genuinamente como Língua. (BRASIL, 2002; 2005).

Contudo, apesar da recente regulamentação, sabe-se que a Libras não é uma língua nova, pois, segundo Gesser (2009), sempre existiu, já que os seus utentes mais significativos, os surdos, também sempre existiram e, interagindo-se entre si, espontaneamente constituíram (e constituem) a língua de sinais.

Segundo Quadros e Karnopp (2004) e Gesser (2009), apesar do seu reconhecimento legal, a Libras recebeu o status de Língua por outras razões, foi por conta dos estudos linguísticos específicos em língua de sinais datados na segunda metade do século XX, estudos estes que elucidaram o fato de que as línguas de sinais detêm todos os níveis linguísticos que constituem uma língua.

De acordo com Pinheiro (2010, p. 49), a Libras:

É uma língua viva, autônoma, capaz de transmitir todo e qualquer conceito, dos mais complexos até os mais abstratos. Os usuários da Libras, podem discutir sobre todo e qualquer assunto, desde economia, política, física, literatura, histórias de humor, etc. É considerada como língua natural, uma vez que, ela surge de forma espontânea no meio da comunidade surda, em face da necessidade destes, em se comunicarem uns com os outros. Diferencia-se da linguagem, por possuir todos os requisitos que a conferem 
como língua, tais como: aspectos fonológicos, morfológicos, sintaxe, semântica e pragmática.

Sendo Língua de Sinais Brasileira, logo, não é universal, já que cada país tem a sua própria língua de sinais. E sendo, então, uma língua de sinais, trata-se de uma modalidade mano-corpo-viso-espacial, ou seja, é expressa por diversas configurações manuais e expressões faciais e corporais, produzida num espaço pré-estabelecido e captada pela percepção visual. (QUADROS, KARNOPP, 2004; GESSER, 2009).

De acordo com as autoras acima referenciadas, a Libras é complexa por possuir gramática própria como as demais línguas, e completa por possibilitar a comunicação de qualquer tema, seja qual for o fenômeno ou a área do conhecimento humano, independentemente da profundidade da abstração. É uma língua viva, e como tal, apresenta diacronia, variações e regionalismos. Além disso, é uma língua autônoma e independente da língua oral, no caso, do Português.

Verifica-se, contudo, que a necessidade do reconhecimento e da oficialização da Libras é algo extremamente valoroso para a comunidade surda, mas, especialmente, para os surdos usuários dessa Língua. Isso porque o respeito pelo surdo e a busca por sua cidadania, dignidade e pleno desenvolvimento, claramente perpassam pelo apreço por sua Língua.

Sendo assim, recentemente uma nova lei sobre a Libras foi sancionada, trata-se da Lei $\mathrm{n}^{\mathrm{o}}$ 13.055/2014, que instituiu como o Dia Nacional da Língua Brasileira de Sinais, a data de 24 de abril de cada ano. (BRASIL, 2014).

A especificidade temática desta produção refere-se à Libras enquanto cadeira acadêmica, dessa forma, a seguir há uma subseção exclusiva sobre esse assunto.

\subsection{A LÍNGUA BRASILEIRA DE SINAIS COMO DISCIPLINA OBRIGATÓRIA NAS LICENCIATURAS}

Como já citado na introdução, foi por meio do Decreto $n^{\circ} 5.626 / 2005$, no seu artigo $3^{\circ}$, parágrafos 1 e 2, que ficou determinada a implantação obrigatória da disciplina de Libras nas licenciaturas de todas as IES do Brasil. 
Essa é, de fato, uma grande conquista no que diz respeito à educação dos surdos, já que supõe-se que o preparo adequado de professores pode favorecer uma educação de qualidade aos alunos surdos em situação de inclusão. Mercado (2012 apud ANDRADE, 2013, p. 42) diz que o mencionado Decreto pode favorecer a construção de "uma nova perspectiva para o atendimento da comunidade surda brasileira, no que se refere à efetivação do acesso dessa comunidade a todos os âmbitos da sociedade em que se encontra inserida, inclusive no setor educacional". Andrade (2013, p. 42-43) contribui afirmando que:

Um dos destaques que se pode verificar na legislação de 2005, na esfera educacional, é a consideração de que os surdos vivem em um país cuja maioria linguística é diferente da sua, portanto deveriam ser preparados sob uma perspectiva bilíngue. [...]. Entendemos que em qualquer processo de formação, seja inicial ou continuada, é necessário prover professores e licenciados com conhecimento na área de educação bilíngue para a melhoria dos processos educacionais ministrados a alunos surdos na rede comum de ensino, em escolas comuns para surdos, em turmas em que a Libras é língua de instrução, ou em sala de recursos.

De acordo com a autora, a educação deve respeitar as particularidades linguísticas do surdo com intuito de promover a acessibilidade comunicativa e, consequentemente, a sua inserção social. É neste sentido que se baseia tal legislação, conforme Vieira-Machado e Lírio (2011), que complementam:

A inserção da LIBRAS no currículo do curso de Pedagogia e das Licenciaturas, proporcionou a abertura para o conhecimento do novo, possibilitou a conhecer e ampliar seus conhecimentos ao direito a participação social. Pois, os alunos começaram a reconhecer os surdos como participantes reais da sociedade, com limitações como qualquer ouvinte. (p. 102).

A importância desse fato não recai apenas na acessibilidade e na inserção social do surdo, mas abrange, também, o aspecto do valor linguístico da Libras, uma vez que esta ainda não tem o reconhecimento social merecido como uma Língua verdadeira, apesar de já haver a sua oficialização legal. Isso, segundo Andrade (2013), decorre da hegemonia das línguas orais 
que imperam fortemente, enquanto que as de sinais ainda são vistas de forma equivocada por conta da trajetória histórica de segregação do surdo e, consequentemente, de sua língua.

Em sua pesquisa sobre a disciplina de Libras na licenciatura, Andrade (2013, p. 46) considerou que:

O certo é que a disciplina provocou reflexões nos estudantes, os quais estão passando por um processo de construção de aprendizagem. Ter outro olhar sobre as diferenças linguísticas e culturais do mundo surdo requer ter uma nova visão sobre esse alunado. Envolve perceber que ele tem direitos, que merece respeito, atenção e consideração dentro de suas especificidades.

A pesquisadora supracitada também menciona a respeito da carga horária da cadeira de Libras nas IES, aproximadamente 50 horas-aula semestrais, explicando que se trata de um quantitativo pequeno de encontros semanais e que não garante o aprendizado da língua para possibilitar a comunicação efetiva com o surdo. Entretanto, a sua relevância se baseia na necessidade, justamente, de se desmistificar conceitos equivocados e de provocar reflexões, assim como expressa a citação acima acerca da disciplina de Libras. Esta, segundo Andrade (2013), pode contribuir, sobremaneira, em relação ao trato com o surdo, pois, apesar de todos os avanços com estudos, pesquisas e políticas públicas, ainda há muito o que se trilhar para o alcance da real inserção social desse grupo minoritário.

Ao tornar acessível a esses alunos [acadêmicos das diferentes licenciaturas] a experiência da Libras e o contato com o movimento surdo na Universidade, um espaço construído essencialmente para o conhecimento, permite que pré-conceitos sejam desconstruídos. (VIEIRA-MACHADO; LÍRIO, 2011, p. 98).

Ademais, isso vai depender, obviamente que, da responsabilidade na organização da ementa referente a essa cadeira, já que cada universidade tem sua autonomia nesse sentido, e, ainda, vai depender do compromisso de cada docente frente à formação dos futuros educadores no que concerne à temática em questão. 
E se a experiência é a abertura para o desconhecido, o novo, o contato com a LIBRAS no aprendizado e na construção da formação dos professores, torna-se talvez o ponto de partida para a propagação das mudanças que venham ocorrer nesta área, já que estes espaços que dão os pontapés iniciais para o desenvolvimento das práticas bilíngues. (VIEIRA-MACHADO; LÍRIO, 2011, p. 99).

A possibilidade que esses alunos [de Pedagogia e das Licenciaturas] tiveram em participar da construção de um novo pensamento, a partir do contato com a LIBRAS, [...], vem para contribuir não só para o processo de formação de professores, mas para compor uma nova cultura brasileira, onde, todos são iguais perante a lei e a todos os cidadãos. (VIEIRA-MACHADO; LÍRIO, 2011, p. 103).

Fica expresso na fala das autoras que o contato e a experiência com essa disciplina são como um pontapé inicial para a possibilidade de uma práxis pedagógica diferenciada em relação ao aluno surdo. Entretanto, mediante a carga horária da disciplina de Libras nas IES, vê-se que o objetivo não é o ensino da língua de fato, mas sim, de conceitos relacionados à língua e aos seus utentes mais significativos, os surdos.

Essa observação está no mesmo viés das graduações de Letras/Libras, Letras/Inglês e Letras/Espanhol, em que não se têm como finalidade o ensino dos idiomas, em si, para uso e aplicação pragmática, mas sim, sobre eles. Logo, segundo Andrade (2013), a aprendizagem da língua fica a cargo da busca autônoma, de cada professor, por formação continuada e por capacitação, para aprimorar a própria atuação profissional. Dessa maneira, há diversos cursos de Libras, Inglês e Espanhol, ofertados em nível técnico ou em curso de idiomas, com intuito de, justamente, ensinar a língua para o uso e a aplicação pragmática.

Diante dessa observação, verifica-se que, ao professor, fica a responsabilidade de constantemente se preparar para toda e qualquer diversidade existente na sociedade, a fim de se evitar a visão homogênea da humanidade e, portanto, respeitar cada qual na sua diferença. A atuação docente é algo delicado e demanda muita dedicação que nem sempre as licenciaturas dão conta de abordar, e, apesar de as graduações oferecerem uma importante base de leitura e de pesquisa, ao se formar, o educador ainda precisará dar continuidade aos estudos, já que, diante da inclusão e da acessibilidade (e não apenas por isso), há uma gama muito diversa de aspectos que, no ato de educar, o professor precisa deter. Neste sentido, Drago (2003 apud VIEIRA-MACHADO; LÍRIO, 2011, p. 101) diz que a "experiência 
adquirida pelo professor deve ser pautada no caráter investigativo e inovador, independente se foi adquirida em seu tempo de magistério ou em seu processo de formação teórica inicial ou continuada".

Esse contexto se reflete, também, no processo educativo do alunado surdo, de maneira que seria importante o professor reconhecer sobre a sua peculiaridade linguística, e, acima de tudo, respeitá-la por meio de uma atuação que, de fato, ensine e propicie a aprendizagem ao aluno surdo. O ideal é que tal conhecimento seja adquirido no período universitário, mas, como dito, a língua, especificamente, pode ser adquirida por meio da busca autônoma de formação extra-acadêmica. Dessa maneira, a importância da disciplina de Libras se concerne na reflexão e na discussão com vistas à dissolução de mitos e de preconceitos existentes na sociedade em relação ao surdo e à Libras, para melhor preparar o futuro professor para o caso de se deparar, em sua sala de aula, com um aluno surdo em situação de inclusão e usuário de Libras.

\section{POSSIBILIDADE DE DESMISTIFICAÇÃO DE CONCEITOS}

Para abordar, exclusivamente, sobre a questão da possibilidade de desmistificação de conceitos em torno do surdo e da Libras, a seguir se encontram duas subseções, a primeira, a respeito dos registros realizados durante a experiência aqui relatada, e a segunda, sobre a confrontação desses registros com toda a teoria expressa no item anterior.

\subsection{SOBRE OS REGISTROS}

Como dito anteriormente, a fase de busca dos registros foi realizada em dois momentos, um no início do semestre letivo de 2014/2, e o outro no seu término. Ocorreu numa universidade pública federal, com treze acadêmicos de licenciatura em Geografia (a escolha do curso ocorreu de forma aleatória), necessariamente, matriculados na disciplina de Libras e que aceitaram participar da investigação.

Vale ressaltar que a disciplina em questão tem carga horária total de cinquenta e uma horas, sendo três horas semanais, portanto, dezessete encontros ao todo. Importa mencionar, ainda, que o(a) professor(a) de Libras segue a ementa da universidade que traz como foco as discussões em torno da surdez e da Libras com base nos Estudos Surdos. Entretanto, o(a) 
professor(a) declarou que há alguma contextualização básica em sinais, mesmo não sendo o objetivo da disciplina.

Ao entrar em sala de aula, na primeira semana do semestre letivo e com autorização prévia, a pesquisadora explanou sobre a temática e os objetivos da pesquisa, e solicitou a participação de todos, porém, somente treze aceitaram participar. Assim, foi entregue uma folha para cada acadêmico e foram proferidos os seguintes questionamentos para que escrevessem de próprio punho: "O que você entende por surdo?" e "O que você entende por Libras?". Nas últimas semanas de aula, a pesquisadora retornou à sala e refez o mesmo procedimento.

Seguem os registros dos alunos:

\section{O QUE VOCÊ ENTENDE POR SURDO?}

\begin{tabular}{|c|c|}
\hline $\begin{array}{c}\text { INIICIO DO SEMESTRE } \\
\end{array}$ & TÉRMINO DO SEMESTRE \\
\hline A-1 "Portador de deficiência." & $\begin{array}{l}\text { A-1 "Conforme diz Gládis Perlin, ser surdo trata-se de uma } \\
\text { experiência visual que demanda numa cultura própria } \\
\text { representada pela língua de sinais e pela forma diferente de } \\
\text { viver." }\end{array}$ \\
\hline $\begin{array}{l}\text { A-2 "Pessoa que tem deficiência auditiva. Ocorre por } \\
\text { problema de formação no útero ou que perdeu audição por } \\
\text { outro motivo que impossibilitou de ouvir sons. O surdo não } \\
\text { fala porque não ouve, mas o que ficou surdo e antes já } \\
\text { falava, fala até bem, o que encontra mais dificuldade é } \\
\text { aquele que nasceu surdo, mas todos necessitam de } \\
\text { acompanhamento de fonoaudiólogo para melhorar a fala." }\end{array}$ & $\begin{array}{l}\text { A-2 "O surdo é um ser humano apenas com surdez, mas isso } \\
\text { não quer dizer que ele seja incapaz. O surdo tem sua } \\
\text { identidade cultural, basta nós o respeitarmos e o preconceito } \\
\text { não deve existir, pois nós não somos melhores que ninguém } \\
\text { e temos que respeitar a todos de forma igualitária." }\end{array}$ \\
\hline $\begin{array}{l}\text { A-3 "Quem tem deficiência auditiva adquirida ou de } \\
\text { nascença, pode ser parcial ou integral." }\end{array}$ & $\begin{array}{l}\text { A-3 "São várias explicações relacionadas à surdez, como a } \\
\text { maneira correta de se referir a estas pessoas, a forma de se } \\
\text { comunicar com estas pessoas, o processo histórico que eles } \\
\text { tiveram que passar com relação às dificuldades de inclusão, } \\
\text { a visão da sociedade em relação a eles, as dificuldades que } \\
\text { eles passam até hoje em buscar um emprego que as } \\
\text { valorizem, pois devemos pensar que ser surdo não é nenhum } \\
\text { defeito e que ser surdo não torna uma pessoa incapaz de } \\
\text { realizar o seu objetivo. A maneira mais correta seria defini- } \\
\text { lo como surdo, pois isso não fica rodeando a maneira de se } \\
\text { referir a essa pessoa, é incorreto dizer surdo-mudo, } \\
\text { mudinho, mudo, deficiente auditivo, portador de deficiência } \\
\text { auditiva, pessoa portadora de deficiência, pois eles não são } \\
\text { mudos, pois eles têm um meio de se comunicar e não são } \\
\text { incapazes. Mas também tem as suas conquistas, a inclusão } \\
\text { da disciplina LIBRAS em universidades, com essa disciplina } \\
\text { a conceituação de surdo é mais discutida, em propor a visão } \\
\text { mais ampla, em descobrir várias coisas sobre eles, a cultura } \\
\text { surda e uma delas e que o objeto principal do surdo é a } \\
\text { visão, este é o bem mais precioso e que eles utilizam muito." }\end{array}$ \\
\hline $\begin{array}{l}\text { A-4 "Deficiente auditivo, pessoa que não tem a capacidade } \\
\text { de ouvir e de interpretar os sons e com dificuldade de se } \\
\text { expressar com quem não é surdo." }\end{array}$ & $\begin{array}{l}\text { A-4 "Segundo Strobel 'ser surdo é uma experiência visual'. } \\
\text { Pelo Decerto } N^{\circ} 5626 / 2005 \text {, art. } 2^{\circ} \text {, 'surdo é a pessoa que } \\
\text { compreende e interage com o mundo por meio de suas } \\
\text { experiências visuais'. O termo aconselhado para se referir a } \\
\text { estas pessoas é simplesmente surdo. Surdez não é doença, a }\end{array}$ \\
\hline
\end{tabular}




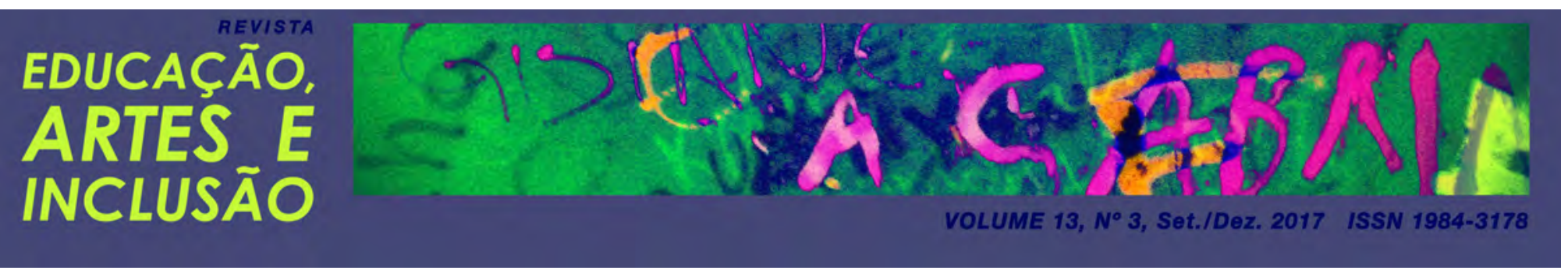

\begin{tabular}{|c|c|}
\hline & $\begin{array}{l}\text { cultura surda deve ser respeitada, pois afinal todos temos } \\
\text { peculiaridades." }\end{array}$ \\
\hline $\begin{array}{l}\text { A-5 "Pessoa que traz em si a deficiência auditiva de não } \\
\text { poder escutar os sons, que é capaz, mas enfrenta o } \\
\text { preconceito da sociedade e a exclusão social. Tem } \\
\text { dificuldade de se fazer entender e de adquirir habilidades } \\
\text { para entender as pessoas. Os deficientes auditivos são tão } \\
\text { capazes e produtivos quanto às pessoas 'normais'." }\end{array}$ & $\begin{array}{l}\text { A-5 "Os surdos são um povo diferente, linguisticamente e } \\
\text { culturalmente, que se manifestam através da língua de } \\
\text { sinais. No Brasil ela se chama LIBRAS - Lingua Brasileira } \\
\text { de Sinais. De um modo geral, para todo ser humano, existe } \\
\text { um conjunto de modos de ser, de pensar, de agir, de } \\
\text { transformar e se adaptar ao mundo. Com o surdo não é } \\
\text { diferente e as formas que ele faz para lidar como isso se } \\
\text { inserem na cultura surda. Os surdos querem ser } \\
\text { reconhecidos como parte de um grupo linguistico-cultural } \\
\text { que tem suas particularidades próprias, que tem sua cultura, } \\
\text { e acima de tudo, que são tão capazes quanto um ouvinte e } \\
\text { também possuem limitaçoses da mesma forma que um ouvinte } \\
\text { pode ter. Surdo é a definição mais correta. Definições como } \\
\text { surdo-mudo, mudinho, mudo, deficiente auditivo, portador } \\
\text { de deficiência auditiva, pessoa portadora de deficiência } \\
\text { auditiva estão fora de uso. A palavra deficiente auditivo } \\
\text { carrega uma carga negativa. Deficiente remete a alguém } \\
\text { que não tem eficiência. Infelizmente esse ainda é um termo } \\
\text { muito utilizado. Já mudez não se diz porque suas } \\
\text { capacidades de falar e, principalmente, de se comunicar } \\
\text { estão intactas. Eles preferem ser chamados de SURDO, } \\
\text { apenas!" }\end{array}$ \\
\hline $\begin{array}{l}\text { A-6 "Pessoa que tem dificuldade ou perda auditiva parcial } \\
\text { ou total de ouvir, é a pessoa deficiente que não escuta, } \\
\text { deficiente auditivo." }\end{array}$ & $\begin{array}{l}\text { A-6 "Pode-se definir o surdo como sujeito que possui } \\
\text { dificuldade auditiva, seja ela leve, moderada, severa e } \\
\text { profunda. O surdo usa uma forma linguística diferenciada } \\
\text { para se comunicar e interage com o mundo por meio da } \\
\text { visão. Os profissionais da área de saúde, ao utilizar o termo } \\
\text { deficiente auditivo, acabam desconsiderando aspectos } \\
\text { psicossociais e culturais da pessoa surda, uma vez que esta } \\
\text { não se considera deficiente, mas diferente." }\end{array}$ \\
\hline $\begin{array}{l}\text { A-7 "São pessoas que têm déficit de atenção e que já nasceu } \\
\text { com esta diferença de não escutar e não falar." }\end{array}$ & $\begin{array}{l}\text { A-7 "De acordo com os estudos pude ver que o ser surdo é } \\
\text { uma experiência visual e que são pessoas diferentes por } \\
\text { terem a sua própria lingua e própria cultura." }\end{array}$ \\
\hline $\begin{array}{l}\text { A-8 "Pessoa com limitação ou deficiência no aparelho } \\
\text { auditivo. Incapacidade física parcial ou total de ouvir ou } \\
\text { identificar os sons emitidos pelo mundo a sua volta. Pessoa } \\
\text { que tem limitaçóes auditivas que a impedem de se } \\
\text { comunicar." }\end{array}$ & $\begin{array}{l}\text { A-8 "As pessoas que têm surdez severa ou profunda podem } \\
\text { ser chamadas simplesmente de surdas. Os próprios surdos } \\
\text { não aceitam serem taxados com o termo "deficiência". Esse } \\
\text { termo pressupõe uma incapacidade que os impossibilita de } \\
\text { viver sua cidadania plena com autonomia. Dentre as } \\
\text { principais terminologias equivocadas podemos encontrar } \\
\text { termos como deficiente auditivo, surdo-mudo, portador de } \\
\text { deficiência, portador de necessidade especial, mudinho, etc., } \\
\text { não devemos utilizar essas terminologias porque o próprio } \\
\text { surdo não se identifica com elas. O surdo prefere ser } \\
\text { chamado de surdo e não aceita ser taxado com } \\
\text { terminologias carregadas de preconceitos que os excluem da } \\
\text { vida em sociedade. A visão tem uma importante função } \\
\text { comunicativa na vida de um surdo. A vida de uma pessoa } \\
\text { surda é uma experiência eminentemente visual. Todo } \\
\text { ativismo surdo busca dar visibilidade à vontade do surdo, as } \\
\text { suas reais necessidades na busca por autonomia. É uma } \\
\text { busca que quer repelir as imposições dos ouvintes. O surdo } \\
\text { não precisa falar como os ouvintes tanto querem. O que ele } \\
\text { precisa é ser aceito como alguém tão capaz quanto o } \\
\text { ouvinte. Quando esse preconceito acabar aí sim pode ser } \\
\text { que o ouvinte realmente ouça o que o surdo tem a dizer. Os } \\
\text { surdos são considerados uma minoria linguística e cultural. } \\
\text { Os artefatos culturais do povo surdo são as peculiaridades } \\
\text { da cultura surda. Além do que é produção material, é 'tudo } \\
\text { que se vê e se sente'. Também se incluem como artefatos: } \\
\text { modos de ser, modos de ver, modos de entender e modos de } \\
\text { transformar o mundo. Os artefatos culturais ilustram uma } \\
\text { cultura. Os principais artefatos culturais que ilustram a }\end{array}$ \\
\hline
\end{tabular}




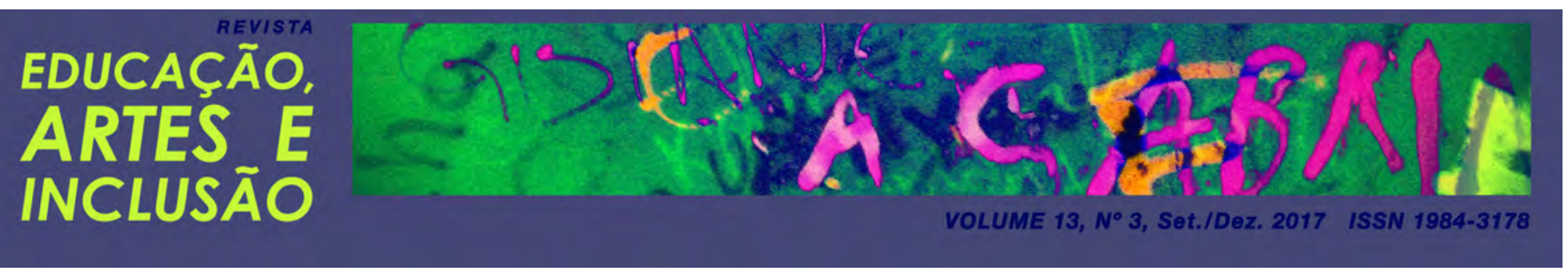

\begin{tabular}{|c|c|}
\hline & $\begin{array}{l}\text { cultura do povo surdo são: experiência visual; linguística; } \\
\text { família; literatura surda; vida social e esportiva; artes } \\
\text { visuais; politica e materiais." }\end{array}$ \\
\hline $\begin{array}{l}\text { A-9 "Pessoa que tem problema de audição, que não escuta } \\
\text { nada e que não ouve som algum, como se ao seu redor não } \\
\text { existisse barulho e som, como se fosse silencioso. Pessoa que } \\
\text { se baseia através das imagens ou da fala em português claro } \\
\text { observando o falante para entender o que ele diz." }\end{array}$ & $\begin{array}{l}\text { A-9 "Nos relatos dos surdos eles dizem que ser surdo é uma } \\
\text { experiência visual. Eles querem ser respeitados em suas } \\
\text { diferenças. Eles têm identidade e cultura próprias, e ainda, } \\
\text { tem a lingua de sinais que é uma particularidade linguística } \\
\text { do povo surdo." }\end{array}$ \\
\hline $\begin{array}{l}\text { A-10 "Indivíduo que não possui audição, que tem que se } \\
\text { comunicar por sinais ou gestos. Pode ter a falta de audição } \\
\text { de nascença ou pela vida. Individuo surdo ou mudo." }\end{array}$ & $\begin{array}{l}\text { A-10 "A comunidade surda que era dominada pelos ouvintes } \\
\text { foi ganhando seu espaço na sociedade através de muitas } \\
\text { lutas e pesquisas de ensino, e com a presença de autores } \\
\text { surdos na sua comunidade, eles passaram a ter uma melhor } \\
\text { representação da sua cultura deixando esclarecido que } \\
\text { todos nós temos nossas limitações e somos capazes de } \\
\text { aprender e nos comunicar. Eles só querem uma educação } \\
\text { que atenda as suas necessidades, eles só querem ser ouvidos } \\
\text { da sua forma de se comunicar, eles só querem a liberdade de } \\
\text { falar a língua de sinais." }\end{array}$ \\
\hline $\begin{array}{l}\text { A-11 "Surdo-mudo é o nome dado à pessoa com deficiência } \\
\text { auditiva, é o estado em que a pessoa não consegue ouvir } \\
\text { sons." }\end{array}$ & $\begin{array}{l}\text { A-11 "O surdo é um ser humano com uma diferença, mas ele } \\
\text { deve ser tratado de forma respeitosa e natural, sem } \\
\text { imposiçóes ou preconceitos. O surdo tem sua identidade } \\
\text { basta respeitarmos suas diferenças, o preconceito é uma } \\
\text { barreira a ser ultrapassada, o não conhecer nos faz } \\
\text { medrosos e inseguros. Com esta disciplina de Libras pude } \\
\text { perceber o quanto é importante nos informarmos e } \\
\text { conhecermos as outras pessoas sem julgar. E quando nos } \\
\text { envolvemos com outras culturas e hábitos, aprendemos a } \\
\text { equilibrar melhor as coisas. Assim, pensamos o porquê eu } \\
\text { seria melhor que ele(a), ou por que a minha comunidade } \\
\text { ouvinte tem que ser dominadora ou superior? Sendo que } \\
\text { poderia ocorrer ao contrário! Sim o direito está para todos, } \\
\text { não somos melhores nem piores, somos diferentes, com } \\
\text { pensamentos, hábitos, jeitos diferentes." }\end{array}$ \\
\hline $\begin{array}{l}\text { A-12 "Indivíduo com deficiência auditiva adquirida ou por } \\
\text { nascença." }\end{array}$ & $\begin{array}{l}\text { A-12 "Os surdos não são considerados deficientes, mas sim, } \\
\text { diferentes, isso porque eles apresentam uma cultura própria } \\
\text { e uma língua diferente, a Libras." }\end{array}$ \\
\hline $\begin{array}{l}\text { A-13 "Pessoa com deficiência auditiva que consegue se } \\
\text { comunicar emitindo sons e algumas palavras." }\end{array}$ & $\begin{array}{l}\text { A-13 "Surdos são pessoas que apresentam diferença } \\
\text { linguística e cultural, pois se comunicam através da Libras e } \\
\text { fazem parte de uma cultura própria." }\end{array}$ \\
\hline
\end{tabular}

TABELA 1 - Registro das respostas referentes ao Surdo, emitidas pelos alunos submetidos à pesquisa no início e no término da disciplina de Língua Brasileira de Sinais.

\section{O QUE VOCÊ ENTENDE POR LIBRAS?}

\begin{tabular}{|c|c|}
\hline INÍCIO DO SEMESTRE & TÉRMINO DO SEMESTRE \\
\hline A-1 "Lingua de sinais." & $\begin{array}{l}\text { A-1 "Libras é considerada uma língua, pois tem todos os } \\
\text { componentes linguísticos e gramaticais, ela não é } \\
\text { considerada uma linguagem e sua transmissão é através do } \\
\text { corpo." }\end{array}$ \\
\hline $\begin{array}{l}\text { A-2 "É a língua brasileira de sinais, importante para a } \\
\text { comunicação e socialização dos surdos com gestos. A língua } \\
\text { brasileira de sinais é a segunda língua oficial do Brasil, } \\
\text { tornando-o bilíngue, pois já tem o português como a } \\
\text { primeira lingua oficial." }\end{array}$ & $\begin{array}{l}\text { A-2 "A Lingua de Sinais é a língua materna dos surdos } \\
\text { brasileiros. Utilizada para comunicação dos surdos e } \\
\text { facilitando a comunicação. A Lingua de Sinais tem a sua } \\
\text { própria gramática. A Lingua de Sinais não é universal, ela } \\
\text { possui sua própria estrutura de país pra país e difere até } \\
\text { mesmo de região pra região de um mesmo país. A Libras tem } \\
\text { muitos anos, mas o seu reconhecimento legal no Brasil é } \\
\text { recente, tem pouco mais de dez anos. Em 2002, foi } \\
\text { promulgada uma lei que reconhece a Lingua Brasileira de } \\
\text { Sinais como meio de comunicação objetiva e de utilização } \\
\text { da comunidade surda do Brasil." }\end{array}$ \\
\hline $\begin{array}{l}\text { A-3 "Linguagem brasileira de sinais obrigatória nas escolas } \\
\text { como forma de interagir com um aluno surdo dentro da sala }\end{array}$ & $\begin{array}{l}\text { A-3 "A Lingua Brasileira de Sinais é muito importante para } \\
\text { os surdos, este é o seu meio de comunicação com os ouvintes }\end{array}$ \\
\hline
\end{tabular}




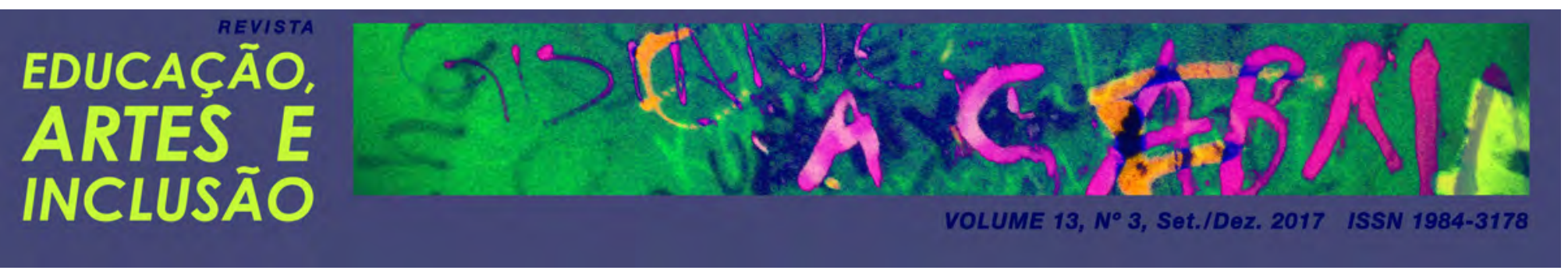

\begin{tabular}{|c|c|}
\hline de aula." & $\begin{array}{l}\text { ou entre surdos, e essa comunicação utiliza as mãos, tem } \\
\text { alguns sinais que precisam ter a expressão fácil diferenciada } \\
\text { para melhorar a compreensão. Como nós pretendemos ser } \\
\text { professores devemos saber um pouco sobre língua de sinais, } \\
\text { pois se um dia tivermos o privilégio de ter um aluno surdo } \\
\text { saberemos um pouco dialogar com esse aluno, lembrando } \\
\text { que há vários cursos profissionalizantes que podem } \\
\text { aperfeiçoar esse conhecimento, só basta querermos." }\end{array}$ \\
\hline $\begin{array}{l}\text { A-4 "Técnica desenvolvida para que os surdos e não surdos } \\
\text { se comuniquem entre si com a lingua de sinais." }\end{array}$ & $\begin{array}{l}\text { A-4 “A lei } N^{\circ} 10436 / 2002 \text { reconhece a LIBRAS como lingua. } \\
\text { O Decreto } N^{\circ} 5626 / 2005 \text { esclarece sobre todas as formas de } \\
\text { obrigatoriedade de implantação e difusão da LIBRAS. É bem } \\
\text { verdade que em muitos casos a lei não é cumprida, porém } \\
\text { devemos observar que foi um grande avanço não só para a } \\
\text { comunidade surda, mas também para a sociedade brasileira } \\
\text { em geral, que assiste de perto a quebra de barreiras } \\
\text { impostas por uma sociedade muitas vezes incapaz de } \\
\text { entender o sofrimento e de respeitar os direitos alheios. } \\
\text { Esperamos que um dia possamos dizer com orgulho que } \\
\text { contribuímos para um Brasil com mais oportunidades e sem } \\
\text { preconceitos, pois como educadores, independentemente dos } \\
\text { alunos com quem estivermos trabalhando, devemos ter o } \\
\text { compromisso de dar nosso melhor, porque não é pelo fato de } \\
\text { vivermos em uma sociedade com tantos problemas, com } \\
\text { tantos maus exemplos dados por nossos "politicos" que } \\
\text { devemos seguir este caminho. Pelo contrário, devemos } \\
\text { construir um caminho honrado, que gere orgulho às pessoas } \\
\text { que estiverem ao nosso redor e a nós mesmos, priorizando } \\
\text { não só a quantidade, mas acima de tudo a qualidade, pois } \\
\text { afinal a inclusão só se dará efetivamente quando a educação } \\
\text { neste país for avaliada não só pela quantidade de seus } \\
\text { frutos, mas também pela qualidade." }\end{array}$ \\
\hline $\begin{array}{l}\text { A-5 "Língua brasileira de sinais, disciplina obrigatória nos } \\
\text { cursos de licenciatura e idioma propriamente dito." }\end{array}$ & $\begin{array}{l}\text { A-5 "A Língua Brasileira de Sinais é a língua utilizada pelo } \\
\text { surdo brasileiro. Assim como a língua portuguesa, ela sofre } \\
\text { variações históricas e regionais. Assim, a língua de sinais } \\
\text { que se usa no Brasil hoje não é exatamente igual a língua de } \\
\text { sinais utilizada aqui na década de 1950. No mesmo sentido, } \\
\text { a língua de sinais utilizada no Rio Grande do Sul tem } \\
\text { pequenas diferenças regionais se compararmos com a língua } \\
\text { de sinais que o cearense usa. Mesmo assim, a língua é uma } \\
\text { só. É a LIBRAS! Ao redor do mudo, cada país tem sua } \\
\text { própria língua de sinais, por isso existem diferenças entre as } \\
\text { línguas de sinais da mesma forma que o inglês é diferente do } \\
\text { português." }\end{array}$ \\
\hline $\begin{array}{l}\text { A-6 "É o meio de comunicação da linguagem de sinais que } \\
\text { as pessoas com deficiência auditiva se comunicam } \\
\text { gesticulando." }\end{array}$ & $\begin{array}{l}\text { A-6 “A Lingua Brasileira de Sinais é a língua brasileira } \\
\text { natural de sinais usada pela maioria dos surdos brasileiros e } \\
\text { ouvintes, reconhecida pela Lei no } 10.436 \text {, de } 24 \text { de abril de } \\
\text { 2002. Libras é a primeira língua dos surdos, a segunda é a } \\
\text { língua portuguesa. Não é artificial, é natural, é brasileira e } \\
\text { não é universal. As linguas de sinais possuem estrutura } \\
\text { própria de pais para pais e diferem até mesmo nas regiões } \\
\text { de um mesmo país, dependendo da cultura daquele } \\
\text { determinado local para construir suas expressões ou } \\
\text { regionalismos. A conquista deste direito traz impacto } \\
\text { significativo na vida social e politica da nação brasileira. } \\
\text { Com a utilização de sua lingua natural, a língua de sinais, } \\
\text { os surdos conseguiram mostrar que são capazes de pensar, } \\
\text { aprender, interagir com o meio, exercer a sua cidadania, } \\
\text { porém, ainda falta uma parcela da comunidade ouvinte que } \\
\text { necessita mudar seu olhar com relação ao ser surdo." }\end{array}$ \\
\hline $\begin{array}{l}\text { A-7 "É o meio de comunicação entre o surdo e o falante } \\
\text { traduzido por sinais e muitas vezes por gestos para o surdo } \\
\text { interagir." }\end{array}$ & $\begin{array}{l}\text { A-7 "Meio de comunicação dos surdos que tem sua } \\
\text { gramática própria e que nasceu naturalmente em meio aos } \\
\text { surdos. É a sua língua materna e dá total condição de os } \\
\text { surdos se expressarem e de entenderem tudo o que acontece } \\
\text { ao seu redor." }\end{array}$ \\
\hline
\end{tabular}




\begin{tabular}{|c|c|}
\hline $\begin{array}{l}\text { A-8 "Idioma baseado numa linguagem de sinais gestuais, } \\
\text { com o uso das mãos, sinais corporais e expressões faciais. } \\
\text { Idioma que permite a comunicação entre surdos e ouvintes } \\
\text { ou entre surdos." }\end{array}$ & $\begin{array}{l}\text { A-8 “Os surdos do Brasil usam a LIBRAS que é uma } \\
\text { peculiaridade deste povo. LIBRAS significa Língua } \\
\text { Brasileira de Sinais. Entrar em contato com LIBRAS foi mais } \\
\text { do que aprender um pouco sobre esta lingua, foi entender a } \\
\text { história de uma minoria marginalizada, foi entender a luta } \\
\text { do povo surdo e das comunidades surdas, foi entender os } \\
\text { porquês deles não aceitarem as imposições e a opressão } \\
\text { histórica dos ouvintes. O que eles querem é ser aceitos como } \\
\text { iguais na sociedade, sem preconceitos que os estigmatizam } \\
\text { como incapazes. LIBRAS não é gesto! LIBRAS não é } \\
\text { mímica! LIBRAS é cultura!"” }\end{array}$ \\
\hline $\begin{array}{l}\text { A-9 "Linguagem de sinais através de gesticulação com os } \\
\text { surdos." }\end{array}$ & $\begin{array}{l}\text { A-9 "Libras é a língua de sinais usada pela maioria dos } \\
\text { surdos brasileiros. Essa lingua é reconhecida por lei. A } \\
\text { Libras não é a simples gesticulação da língua portuguesa e } \\
\text { sim uma língua à parte. Ela faz parte da cultura do surdo." }\end{array}$ \\
\hline $\begin{array}{l}\text { A-10 "Para os surdos é a língua oficial por sinais ou } \\
\text { gestos." }\end{array}$ & $\begin{array}{l}\text { A-10 “A Língua Brasileira de Sinais é a língua utilizada pelo } \\
\text { surdo brasileiro. Ela é natural, histórica e dinâmica. Cada } \\
\text { país tem sua própria língua de sinais. Através dela foi } \\
\text { estabelecida para o surdo a comunicação em qualquer } \\
\text { situação, seja ela em arte, religião, ciência e outros." }\end{array}$ \\
\hline $\begin{array}{l}\text { A-11 "Língua internacional de sinais, diversos países } \\
\text { aceitam e possuem a libras como sua segunda língua oficial, } \\
\text { e fazem dela um aprendizado obrigatório principalmente no } \\
\text { meio acadêmico. A libras surge como uma estrutura para a } \\
\text { comunicação e expressão voltada aos diversos níveis de } \\
\text { aprendizado a fim de incorporar as pessoas com déficits de } \\
\text { aprendizagem, seja ela visual, auditiva e fisica." }\end{array}$ & $\begin{array}{l}\text { A-11 "A comunicação do surdo é através de sinais, onde } \\
\text { antigamente era conhecida como mímicas, gestos, etc. } \\
\text { LIBRAS é a primeira língua dos surdos, não é artificial, nem } \\
\text { universal, muito menos uma versão sinalizada da língua } \\
\text { oral. A modalidade da LIBRAS é corporal, visual e } \\
\text { espacial.", }\end{array}$ \\
\hline $\begin{array}{l}\text { A-12 "É uma língua como o inglês, espanhol, entre outras. } \\
\text { Essa linguagem é um meio de comunicação para os surdos. } \\
\text { A libras é um idioma para o surdo e para quem precisa se } \\
\text { comunicar com um surdo." }\end{array}$ & $\begin{array}{l}\text { A-12 "Libras é a língua de sinais dos surdos do Brasil que } \\
\text { foi reconhecida pela lei } n^{\circ} 10436 / 2002 . \text { Ela surgiu } \\
\text { naturalmente pela necessidade de os surdos se } \\
\text { comunicarem. Assim como as linguas faladas, cada país tem } \\
\text { a sua própria língua de sinais, mas existem variações } \\
\text { regionais na Libras." }\end{array}$ \\
\hline $\begin{array}{l}\text { A-13 "É uma linguagem de sinais para nós comunicarmos } \\
\text { com a pessoa surda." }\end{array}$ & $\begin{array}{l}\text { A-13 "Libras é a língua dos surdos que foi reconhecida pela } \\
\text { lei número } 10.436 \text { de } 24 \text { de abril de } 2002 \text {. Esta disciplina foi } \\
\text { muito rica e é útil para os acadêmicos e futuros professores, } \\
\text { ela possibilitou um melhor entendimento sobre a surdez." }\end{array}$ \\
\hline
\end{tabular}

TABELA 2 - Registro das respostas referentes à Libras, emitidas pelos alunos submetidos à pesquisa no início e no término da disciplina de Língua Brasileira de Sinais.

No item que segue se encontra a análise geral das respostas dos acadêmicos correlacionadas com os preceitos dos Estudos Surdos.

\subsection{CORRELAÇÃO DOS REGISTROS COM OS ESTUDOS SURDOS}

Analisando as respostas dos acadêmicos que participaram desta investigação, notou-se que houve reconceituação acerca dos motes centrais deste trabalho, a saber, o surdo e a Libras. De acordo com a hipótese inicial, viu-se que no começo da disciplina de Libras os alunos se basearam no senso comum para emitirem seus registros a respeito dos dois temas, mas, depois de um semestre de leituras, estudos e discussões, houve alteração em suas conceituações, agora com base na fundamentação possibilitada pela disciplina mencionada. 
Nas próximas linhas se situam as verificações e as comprovações a respeito das mudanças de conceitos, exclusivamente, sobre o surdo.

Nas respostas do início do semestre letivo, inclusive algumas um tanto lacônicas, justificando o distanciamento com a temática, percebeu-se, na maioria delas, que houve muita ênfase no aspecto físico da surdez, ou seja, na falta da audição, propriamente dita. A grande maioria dos acadêmicos se referiu ao surdo utilizando a expressão deficiente auditivo (A-2, A-3, A-4, A-5, A-6, A-8, A-12, A-13), outros utilizaram portador de deficiência (A-1), pessoa com problema de audição (A-9), surdo-mudo (A-11) e mudo (A-10), formas estas destoadas da perspectiva dos Estudos Surdos, inclusive com complementos nas respostas que também divergem dessa perspectiva teórica. Houve, ainda, um(a) dos(as) alunos(as) que relacionou surdez com déficit de atenção (A-7).

Um(a) dos(as) participantes acreditava ser fundamental a fala oral para viver em sociedade, declarando que o surdo necessita de acompanhamento com fonoaudiólogo para aprender a oralizar (A-2). Outros aspectos observados foram: que eles não falam (sentido de oralizar) porque não ouvem (A-2), que, necessariamente, fazem a leitura labial (A-9), e ainda, que usam de gestos (A-10) ou emitem sons e poucas palavras para se comunicarem (A-13). Alguns participantes mencionaram que os surdos apresentam dificuldades para se expressarem, para interagirem e para serem compreendidos pelos ouvintes (A-2, A-4, A-5, A$8)$.

Já no final do semestre letivo, notou-se alteração em toda essa visão acerca do surdo. As novas respostas concerniram na questão da experiência visual do surdo (A-1, A-3, A-4, A6, A-7, A-8, A-9) e, de forma unânime, no entendimento/reconhecimento sobre a sua diferença linguística, cultural e identitária. Um(a) dos(as) participantes citou diversos artefatos culturais do povo surdo (A-8): literatura surda, esporte, entre outros.

As respostas convergiram com o que diz Perlin (2003) sobre o surdo ter a experiência visual como fundamental para a sua constituição identitária e concepção de mundo, e sobre a sua diferença linguística e cultural.

No que concerne à terminologia, verificou-se, na unanimidade das respostas, que os alunos assimilaram que a forma mais adequada se refere ao termo surdo, como se pode observar na segunda coluna da primeira tabela. Dois(uas) dos(as) acadêmicos(as) aludiram 
sobre a surdez não ser uma doença e que todos as pessoas (surdos e ouvintes) têm limitações (A-4, A-10).

As respostas foram convergentes com Gesser (2009) e demais autores dos Estudos Surdos, no que diz respeito à terminologia apropriada pelo viés cultural-identitário, que se refere ao termo surdo.

Alguns acadêmicos enfatizaram motes importantes como humanidade, cidadania e igualdade para o surdo (A-2, A-4, A-8, A-11), e outros demonstraram que passaram a considerar esses sujeitos como seres humanos totalmente capazes e dignos de respeito (A-2, A-3, A-5, A-8, A-10, A-11). Em várias respostas ficou evidenciada a conscientização da necessidade de luta contra os preconceitos, a inacessibilidade, a exclusão, e contra as coerções e imposições ouvintistas (sentido de dominação/superioridade/colonização histórica) (A-2, A3, A-8, A-10, A-11).

Para autores dos Estudos Surdos (PERLIN, 2003; QUADROS, KARNOPP, 2004; STROBEL, 2008; GESSER, 2009), a surdez não é entendida como doença, muito menos que o surdo seja incapaz, pelo contrário, é um ser humano digno de respeito e de cidadania. Os mesmos autores declaram que a comunidade surda tem lutado há tempos contra o preconceito e a colonização ouvintista, e por direitos específicos para a minoria surda na direção da inclusão e da acessibilidade.

Houve respostas com menção a importantes conquistas dos surdos pelo fato de fazerem parte de uma minoria linguística e cultural, como é o caso da Lei n ${ }^{\circ}$ 10.436/2002 e do Decreto $n^{\circ}$ 5.626/2005 (A-2, A-3, A-4, A-8, A-10). Mencionaram, inclusive, sobre a inserção da Libras na academia, pois, segundo duas respostas, a partir desse fato pode se discutir, na universidade, em torno da surdez e de tudo o que a ela implica diante da perspectiva dos Estudos Surdos (A-3, A-11).

Um(a) dos(as) alunos(as) pontuou questões também relevantes (A-10): que os surdos querem uma educação que atenda as suas necessidades, e querem ser repeitados nas suas especificidades linguísticas.

A comunidade surda tem, realmente, conquistado direitos, como foi o caso do reconhecimento oficial da Libras pela Lei $\mathrm{n}^{\circ} 10.436 / 2002$, regulamentada pelo Decreto 
5.626/2005, conforme os próprios alunos mencionaram. O Decreto, por sua vez, traz a obrigatoriedade da inserção da Libras como disciplina acadêmica nas licenciaturas, e traz outros elementos importantes no que tange à educação do surdo em suas especificidades. (BRASIL, 2002; 2005).

Nas próximas linhas se situam as verificações e as comprovações a respeito da relevante mudança de conceitos, exclusivamente, sobre a Libras.

$\mathrm{Na}$ maioria das respostas do início do semestre letivo, ficou evidente a conceituação da Libras por meio de vários equívocos, tais como, linguagem de sinais (A-3, A-6, A-8, A-9, A-12, A-13), gestos/gesticulação/gesticulando (A-2, A-6, A-7, A-8, A-9, A-10), técnica de comunicação desenvolvida para ajudar na comunicação com os surdos (A-4), linguagem de sinais obrigatória somente para a interação dos surdos nas escolas (A-3), meio de comunicação entre o surdo e o não-surdo por sinais ou por gestos para o surdo interagir (A-7), e linguagem de sinais para os ouvintes se comunicarem com a pessoa surda (A-13).

Outro(a) aluno(a) afirmou equivocadamente que a Libras seria uma língua internacional de sinais, de maneira que diversos países a aceitam e a possuem como segunda Língua oficial, fazendo dela um aprendizado obrigatório, principalmente, no meio acadêmico (A-11). Este(a) mesmo(a) aluno(a) se equivocou, também, ao dizer que a Libras surgiu como uma estrutura para a comunicação e a expressão voltada aos diversos níveis de aprendizado, a fim de incorporar as pessoas com déficit de aprendizagem, seja ela visual, auditiva e física (A$11)$.

Contudo, seis alunos responderam de forma aproximada aos Estudos Surdos no que diz respeito à Libras. Um(a) deles(as) disse que se trata de Língua de Sinais (A-1). Dois(uas) deles(as) a definiram como Língua Brasileira de Sinais, considerando-a como uma das Línguas oficiais do Brasil, e colocando-a como importante para a comunicação e a socialização dos surdos, apesar de que um(a) deles(as) mencionou também a palavra gestos (A-2, A-5). Já o(a) quarto(a) aluno(a) aludiu sobre o reconhecimento da Libras como idioma que permite a comunicação entre surdos e entre surdos e ouvintes, e sobre o aspecto do uso das mãos, do corpo e das expressões faciais, apesar de tê-la definido, erroneamente, como uma linguagem gestual (A-8). A quinta resposta aproximada deixou claro o reconhecimento da Libras como Língua oficial, mas, que sua expressão ocorre por meio de gestos (A-10). A 
sexta, por sua vez, se referiu à Libras como uma Língua tal qual o Inglês, o Espanhol, entre outras, e que seria como um idioma, embora tenha mencionado, contraditoriamente, a palavra linguagem (A-12).

Já nos registros do final do semestre letivo, notou-se alteração em toda essa visão acerca da Libras. As novas respostas concordaram que Libras é a Língua Brasileira de Sinais (A-2, A-3, A-5, A-6, A-8, A-9, A-10, A-12), e que, verdadeiramente, trata-se de uma Língua (unânime), pois possui todos os componentes linguísticos necessários para, assim, ser definida $(\mathrm{A}-1)$.

Aludiram, também, sobre a sua estrutura gramatical própria e independente da Língua Portuguesa (A-1, A-2, A-6, A-7), e concordaram que a transmissão se dá em um determinado espaço (A-11), pelas mãos (A-3), pelo corpo (A-1, A-11) e pelas expressões faciais (A-3), e, ainda, que a recepção é visual (A-11). Dois(uas) aluno(as) afirmaram que a Libras não é uma versão sinalizada da Língua Portuguesa (A-9, A-11).

Os acadêmicos responderam que a Libras deve ser reconhecida e respeitada por ser o principal meio de comunicação de muitos surdos brasileiros (unânime). Dois(uas) dos(as) participantes mencionaram a respeito de que, por meio da Libras, o surdo tem total condição de expressão e de compreensão, de forma que, por ela há a possibilidade de comunicação em qualquer situação (A-7, A-10).

Responderam sobre a questão do seu surgimento de modo espontâneo (não sendo, portanto, artificial) em meio aos surdos (A-6, A-7, A-10, A-11, A-12), deixaram claro o entendimento de que a Libras não é universal (A-5, A-6, A-11), pois cada país tem a sua língua de sinais, assim como ocorre com as orais (A-2, A-5, A-6, A-10, A-12), e sobre o aspecto das variações históricas e regionais (A-2, A-5, A-6, A-10, A-12). Um(a) acadêmico(a) mencionou que a Libras não é mímica ou simples gestos (A-8), mas que, em concordância com outro(a) aluno, disse que a Libras faz parte da cultura do povo surdo (A-8, A-9).

Em suas respostas viu-se compreensão teórica sobre a Libras. De acordo com Gesser (2009), a Língua Brasileira de Sinais trata-se, verdadeiramente, de uma Língua com todos os níveis linguísticos e com estrutura gramatical específica e complexa, portanto, não se trata de uma versão sinalizada da Língua Portuguesa, sendo totalmente autônoma e independente desta. A autora diz que sua expressão ocorre pela modalidade mano-corporal e espacio-visual, 
tendo total condição de comunicação de qualquer que seja o assunto. E, ainda, conforme Gesser (2009), essa Língua faz parte da cultura do povo surdo, surgiu espontaneamente entre os mesmos, não é artificial, não é mímica, não é gestos, não é universal, e apresenta variações históricas e regionais.

Seis acadêmicos(as) lembraram da legitimidade da Libras através do seu aspecto legal, e disseram que, apesar de a Língua de Sinais ter muitos anos, a sua oficialização no Brasil tem pouco mais de uma década, já que a Lei $\mathrm{n}^{\circ} 10.436$ a regularizou como Língua verdadeira somente em 2002 (A-2, A-4, A-6, A-9, A-12, A-13). Um(a) destes(as) seis alunos(as) lembrou-se, também, do Decreto $n^{0} 5.626 / 2005$, afirmando que este esclarece sobre todas as formas de obrigatoriedade de implantação e de difusão da Libras (A-4). Sobre isso, ele(a) disse que ainda não há o cumprimento total da Lei, mas que, de qualquer maneira, trata-se de um grande avanço, não só para a comunidade surda, mas também, para a sociedade brasileira, pois, essa política pode contribuir para a quebra de barreiras impostas pelo preconceito, pela desigualdade, pelo desrespeito e pela falta de conhecimento (A-4). Este(a) mesmo(a) acadêmico(a) mencionou que espera que um dia se possa dizer, com orgulho, que o momento atual contribuiu para um Brasil com mais oportunidades e sem preconceitos (A-4). Disse, também, que, como educadores, independentemente dos alunos com quem se trabalha, precisam ter o compromisso em oferecer o melhor de si, porque não é pelo fato de se viver numa sociedade com tantos problemas e com tanta corrupção que se deve seguir o mesmo caminho, pelo contrário, deve-se construir um caminho honrado, que gere orgulho, priorizando não só a quantidade, mas, acima de tudo, a qualidade no processo educativo (A$4)$.

Outro(a) aluno(a) demonstrou conscientização a respeito do direito conquistado pelos surdos no que concerne à Libras, pois para ele(a), esse fator proporciona cidadania e possibilita que os surdos demonstrem que são tão capazes quanto os ouvintes, apesar de entender que ainda falta algum caminho a ser percorrido na direção da mudança total do olhar equivocado da sociedade em relação ao sujeito surdo (A-6).

Outro(a) aluno(a) complementou em sua segunda resposta que quem pretende ser professor deve saber um pouco sobre a Língua de Sinais, pois se um dia tiver o privilégio de ter um aluno surdo saberá dialogar um pouco com esse aluno, e para isso, o(a) acadêmico(a) 
em questão lembrou que há vários cursos que podem favorecer o aperfeiçoamento sobre esse conhecimento, basta que o professor, definitivamente, queira (A-3).

Houve outras duas respostas totalmente convergentes com o intuito desta investigação. Uma delas afirmou que a disciplina em questão foi muito rica e útil para os acadêmicos e futuros professores, pois ela possibilitou um melhor entendimento sobre a surdez e tudo o que a ela implica (A-13). E a outra afirmou que o contato com a disciplina de Libras foi muito mais do que possibilitar o aprendizado sobre a Língua, pois, foi na realidade, o entendimento sobre a história de uma minoria marginalizada, sobre a luta do povo surdo e das comunidades surdas, e sobre os porquês de os surdos não aceitarem as imposições e a opressão histórica dos ouvintes (A-8). Este(a) aluno(a) referiu-se, ainda, sobre ter compreendido que os surdos querem ser aceitos na sociedade sem preconceitos e sem o estigma da incapacidade (A-8).

Pode-se notar que houve significativa mudança na concepção dos participantes no que se refere aos dois temas verificadas: o surdo e a Libras. As segundas respostas, abalizadas e propiciadas pela disciplina de Libras, passaram a convergir com a fundamentação teórica desta produção, a partir da perspectiva dos Estudos Surdos. Dessa forma, nota-se que a disciplina tem importância fundamental na formação teórica dos futuros professores.

\section{CONSIDERAÇÕES FINAIS}

Diante do exposto nas seções anteriores, verifica-se que o intento da presente investigação foi alcançado, visto que todos os colaboradores apresentaram significativas alterações em suas respostas finais, desmistificando, assim, os conceitos anteriormente equivocados sobre o surdo e a Libras. Dessa maneira, considera-se que a disciplina de Libras na academia tem importância para a adequação de conhecimentos, de modo que, no início do semestre letivo, as respostas dos acadêmicos foram baseadas no senso comum, em mitos e em preconceitos, e no seu término, as novas respostas se mostraram fundamentadas nos preceitos dos Estudos Surdos.

O Decreto $\mathrm{n}^{\mathrm{o}}$ 5.626/2005 tem pertinência quando estabelece a inclusão da Libras como disciplina curricular nos cursos de licenciaturas por todo o Brasil. Além de propiciar a 
desmistificação de conceitos equivocados e de favorecer o preparo dos futuros professores para uma prática pedagógica refletida diante da diferença, no caso, a surdez, o Decreto representa, também, uma das maiores conquistas dos surdos brasileiros. Mesmo que de forma paulatina, esse documento vem sendo obedecido, e um bom exemplo desse fato está na própria universidade investigada, já que tal instituição adequou os currículos das licenciaturas com a inserção da disciplina em questão, além de outras IES que vêm contratando e efetivando professores para a cadeira de Libras por todo o país. Obviamente que essa não se trata da única providência do referido Decreto, pois este traz muitas outras importantíssimas disposições em favor da minoria surda, especialmente no que se refere à inclusão e à acessibilidade.

Diante da constatação desta, vislumbra-se um futuro diferenciado para os surdos, pois, através da busca da adequação na formação para o magistério, pode-se fomentar uma ação responsiva na sociedade como um todo. Espera-se, portanto, que essa ação contribua com a diminuição da reprodução de mitos e de preconceitos no meio educacional, e, consequentemente, na sociedade.

A educação é uma prática social e, inevitavelmente, intervém na realidade social. Sendo assim, a formação para a atuação docente precisaria se ater às diversas situações marcadamente heterogêneas, para que a práxis pedagógica seja, de fato, responsável e acautelada, pois a docência lida diretamente com vidas em plena formação!

\section{REFERÊNCIAS}

ANDRADE, Érica. Estudo da Disciplina de Libras em Duas Licenciaturas no Litoral do Paraná. Divers@ Revista Eletrônica Interdisciplinar, Matinhos, v. 6, n. 1, p. 39-51, jan/jun, 2013.

BRASIL. Lei $\mathrm{n}^{\circ}$ 10.436, de 24 de abril de 2002. Dispõe sobre a Língua Brasileira de Sinais - Libras e dá outras providências. Diário Oficial [da República Federativa do Brasil], Poder Legislativo, Brasília, DF, 25 abr. 2002. p. 23. [recurso eletrônico]. Disponível em: $<$ http://www.planalto.gov.br/ccivil_03/leis/2002/L10436.htm>. Acesso em: 01 nov. 2014.

BRASIL. Decreto $\mathrm{n}^{0}$ 5.626, de 22 de dezembro de 2005. Regulamenta a Lei $\mathrm{n}^{\circ} 10.436$, de 24 de abril de 2002, que dispõe sobre a Língua Brasileira de Sinais - Libras, e o art. 18 da Lei no 10.098, de 19 de dezembro de 2000. Diário Oficial [da República Federativa do Brasil], Poder Executivo, Brasília, DF, 23 dez. 2005. p. 28. [recurso eletrônico]. Disponível em: $<$ http://www.planalto.gov.br/ccivil_03/_ato2004-2006/2005/decreto/d5626.htm>. Acesso em: 01 nov. 2014. 
BRASIL. Lei $\mathrm{n}^{\circ}$ 13.055, de 22 de dezembro de 2014. Institui o Dia Nacional da Língua Brasileira de Sinais - LIBRAS e dispõe sobre sua comemoração. Diário Oficial [da República Federativa do Brasil], Poder Executivo, Brasília, DF, 23 dez. 2014. p. 01. [recurso eletrônico]. Disponível em: $<$ https://www.planalto.gov.br/ccivil_03/_ato2011-2014/2014/lei/113055.htm>. Acesso em: 11 fev. 2015.

DEUS, Klênia. Língua Brasileira de Sinais: Libras III. São Paulo: Know How, 2010.

GESSER, Audrei. Libras? Que Língua é essa?: Crenças e preconceitos em torno da língua de sinais e da realidade surda. São Paulo: Parábola, 2009.

PERLIN, Gladis. O Ser e o Estar sendo Surdos: alteridade, diferença e identidade. Porto Alegre: UFRGS, 2003. 156 p. Tese (Doutorado em Educação) - Programa de Pós-Graduação em Educação, Faculdade de Educação, Universidade Federal do Rio Grande do Sul, Porto Alegre, 2003.

PINHEIRO, Lucineide. Língua Brasileira de Sinais: Libras I. São Paulo: Know How, 2010.

QUADROS, Ronice; KARNOPP, Lodenir. Língua de Sinais Brasileira: estudos linguísticos. Porto Alegre: Artmed, 2004.

SILVEIRA, Carolina; REZENDE, Patrícia. Os discursos sobre a educação de surdos na revista Nova Escola. In: QUADROS, Ronice. (Org.). Estudos Surdos III: série pesquisas. Petrópolis: Arara Azul, 2008. p. 58-81.

STROBEL, Karin. As imagens do outro sobre Cultura Surda. Florianópolis: UFSC, 2008.

VELOSO, Éden; MAIA, Valdeci. Aprenda Libras com Eficiência e Rapidez. Curitiba: Mão Sinais, 2011.

VIEIRA-MACHADO, Lucyenne; LÍRIO, Larissa. A Disciplina de Libras e a Formação Inicial dos Professores: experiências dos alunos de graduação em Pedagogia na Universidade Federal do Espírito Santo. Revista FACEVV, Vila Velha, n. 6, p. 96-104, jan/jun 2011. 